\title{
The Intention to Conduct Internal Whistleblowing During Covid-19: Finding the Influencing Factors
}

\author{
Arief Hidayatullah Khamainy ${ }^{1}$, Moh. Faisol ${ }^{2}$ \\ \{ariefkhamainy@wiraraja.ac.id $\left.{ }^{1}\right\}$
}

Accounting Department, Faculty of Economics and Business, Universitas Wiraraja, Indonesia ${ }^{1,2}$

\begin{abstract}
This research aims to analyze and examine the effect of each of the variables of ethical relativism orientation, moral intensity, organizational commitment, and professional identity on the intention to carry out internal whistleblowing with legal protection as a moderating variable during the Covid-19 pandemic. The population used in this research were employees of the Government of Sumenep Regency. The samples were determined using purposive sampling method. Data collection used a questionnaire distributed to 100 respondents, but only 75 questionnaires were returned. Data validity test and reliability test were used to test the quality of the data, then the classical assumption test and statistical $t$ test using the SPSS 20 program were used in this research. The results show that the ethical orientation of relativism, moral intensity, organizational commitment, and professional identity are all factors that influence the intention to conduct internal whistleblowing. However, the variable of legal protection can't moderate these four variables to increase employee intention to conduct internal whistleblowing. The results of this research are expected to be used as new reference material and considerations, especially for the Sumenep Regency Government in the future, regarding several factors that they can maximize in order to encourage each member of the organization to always be motivated to take whistleblowing action.
\end{abstract}

Keywords: Internal whistleblowing intention, relativism ethical orientation, moral intensity, organizational commitment, professional identity, legal protection

\section{Introduction}

Whistleblowing is an attempt to reveal the existence of fraudulent practices, illegal practices, or other forms of fraudulent practices committed by individuals or groups that are part of an organization or agency (active members or former members in this case staff / employees) that occur where the person is employed or has worked. Disclosure is made to another person or organization with the hope of taking action against the perpetrator of the fraud [1]. According to Husniati, et al [2] over the last few decades, issues regarding whistleblowing have become a concern by several circles in the global world, because the existence of whistleblowing is considered a means of disclosing fraud cases.

Kreshastuti and Prastiwi [3] add that one way to reveal accounting violations so that it can restore public confidence is to do whistleblowing. Whistleblowing is reporting made by members of the organization (active or non-active) regarding violations, illegal or immoral acts to parties inside or outside the organization. Regulators are trying to restore public confidence in the accounting profession. In Indonesia, the Whistleblowing System (WBS) Reporting 
System Guidelines (WBS) were issued by the National Committee on Governance (KNKG) on November 10, 2008. The regulation requires accountants to report management fraud to the appropriate policy makers. So that, either directly or indirectly, a whistleblower in an organization is actually needed by an agency to help reveal the existence of fraud in an agency.

Wahyuni and Nova [4] argue that someone who commits whistleblowing can occur from internal or even external parties from an organization. The difference between the two is to whom the fraud case is reported. Internal whistleblowing is when an employee becomes aware of fraud then reports it to their supervisor. Meanwhile, external whistleblowing occurs when an employee who is aware of fraud in the agency then reports it to parties outside the agency or organization because they think that the fraud has harmed the community. The practice of whistleblowing is very important, but in fact the intention to carry out this practice is still rare in Indonesia, because most of them prefer to remain silent rather than have to report fraud in the hope that they feel more secure in their position if they do not practice this practice. According to Husniati, et al [2] there are four factors that encourage whistleblowing in organizations, namely ethical relativism, moral intensity, organizational commitment, and professional identity. The act of whistleblowing can also be related to prosocial organizational behavior theory.

Whistleblowing is a form of prosocial action by organizational members to convey directions, procedures, or policies which according to them may be unethical, illegal or catastrophic for the long-term goals of the organization to individuals or other bodies in a position to take corrective action. Prosocial organizational behavior theory emphasizes that the whistleblowing action of an employee shows a form of employee commitment to protect the organization from threats of unethical or illegal things.

Several previous studies related to the four factors that encourage whistleblowing, there are still differences in results, such as in the research of Lestari and Yaya [1] with the research of Husniati et., Al [2]. In addition, this research is very important to do because the practice of whistleblower is very important to be carried out and cultivated to disclose acts of fraud that have occurred so that this will also help the Sumenep Regency Government in maintaining the achievement of the Unqualified opinion financial statements obtained in recent years. With the Covid-19 pandemic as it is now, all activities are completely limited, so this also encourages researchers to raise this research during the pandemic to find out the intention of whistleblowing with limited activities.

The problem formulations in this study are: (1) Is the ethical orientation of relativism a factor that influences the intention to conduct internal whistleblowing? (2) Is moral intensity a factor influencing the intention to conduct internal whistleblowing? (3) Is organizational commitment a factor affecting the intention to conduct internal whistleblowing? (4) Is professional identity a factor affecting the intention to conduct internal whistleblowing? (5) Is legal protection a moderating variable for each of the variables of ethical relativism orientation, moral intensity, organizational commitment, and professional identity towards the intention to conduct internal whistleblowing? 


\section{Methods}

\subsection{Population and sample}

The population in this study were all staff / employees at the Regional Work Unit of Sumenep Regency. The sampling technique uses purposive sampling method, the characteristics of the sampling are as follows: 1. All staff / employees working in the Regional Work Unit of Sumenep Regency 2. The staff / employees who have Group 3 and below (who do not occupy certain positions) 3. Minimum work period of 5 years in the same Regional Work Unit. The type of data used in this study is primary data. Primary data was conducted by survey method, namely primary data collection method using written questions. The survey method used is by distributing questionnaires to respondents in the form of written questions.

\subsection{Data collection technique}

Data were collected from the results of written answers from respondents. Respondents will be given columns to choose conditions that describe themselves. Respondents simply give a check mark ( $\square$ ) or cross (X) with 5 answer choices, namely STS which means that the respondent strongly disagrees with the question given, TS which means that the respondent does not agree with the question given, $\mathrm{N}$ which means that the respondent is neutral towards the question given, the next choice is $S$ which indicates that the respondent agrees to the question given, then the SS choice which indicates that the respondent strongly agrees with the question given. In this study the population used was all staff / employees at the Regional Government Work Unit of the Sumenep Regency Government. The distribution of questionnaires in this study was carried out by giving directly to employees who work in the Regional Government Work Unit of the Sumenep Regency Government. The questionnaire was distributed directly to all Regional Work Units of the Sumenep Regency Government, totaling 25 agencies. Of the 100 questionnaires distributed, 75 returned questionnaires $(75 \%)$, so that this number is a questionnaire that can be processed by researchers.

\subsection{Data analysis}

The data analysis used was quantitative data analysis so that descriptive statistical tests, data quality tests, and classic assumption tests were used in this study. Then to test the effect of each variable, the $t$ test is used and the moderation test is used to test whether the moderating variable can moderate each of the independent variables on the dependent variable used.

\section{Results and Discussion}

\subsection{Result}

Before testing the effect of each of the factors that affect the intention to conduct internal whistleblowing, the data in this study have been tested for validity, reliability and classical assumption. 


\subsubsection{Determination coefficient test results (R2)}

Table 1.

As for the test results of the coefficient of determination can be presented in the following

Table 1. Determination Coefficient Test Results

\begin{tabular}{lllll}
\hline Model & R & R Square & Adjusted R Square & Std. Error of the Estimate \\
\hline 1 & $0,623^{\text {a }}$ & 0,388 & 0,344 & 1,491 \\
\hline
\end{tabular}

Based on the table, the Adjusted R Square value is 0.344 , which means that $34.4 \%$ of the intention to do internal whistleblowing can be explained by the variables of ethical relativism orientation, moral intensity, organizational commitment, professional identity and legal protection, while the remaining $65.6 \%$ is explained by variables. others that were not used in this study.

\subsubsection{T test results}

Table 2. $t$ test results

\begin{tabular}{|c|c|c|c|c|c|c|}
\hline & \multirow{2}{*}{ Model } & \multicolumn{2}{|c|}{$\begin{array}{l}\text { Unstandardized } \\
\text { Coefficients }\end{array}$} & \multirow{2}{*}{$\begin{array}{l}\text { Standardized } \\
\text { Coefficients } \\
\text { Beta }\end{array}$} & \multirow{2}{*}{$\mathbf{t}$} & \multirow{2}{*}{ Sig. } \\
\hline & & B & $\begin{array}{l}\text { Std. } \\
\text { Error }\end{array}$ & & & \\
\hline \multirow{5}{*}{1} & (Constant) & $-1,092$ & 3,859 & & $-2,83$ & 0,778 \\
\hline & $\begin{array}{l}\text { The ethical orientation of } \\
\text { relativism }\end{array}$ & 0,269 & 0,101 & 0,257 & 2,670 & 0,009 \\
\hline & Moral intensity & 0,397 & 0,087 & 0,459 & 4,587 & 0,000 \\
\hline & Organizational commitment & 0,193 & 0,087 & 0,225 & 2,222 & 0,029 \\
\hline & Professional identity & 0,292 & 0,086 & 0,320 & 3,396 & 0,001 \\
\hline
\end{tabular}

These results can be interpreted as follows:

- The regression coefficient of the Ethical Relativism Orientation variable shows the number 0.269 with a positive coefficient direction, this indicates that the higher the Relativism Ethical Orientation value of a staff/employee will increase the intention to do internal whistleblowing with a significance value of $0.009<0.05$.

- The regression coefficient of the Moral Intensity variable shows the number 0.397 with a positive coefficient direction, this indicates that the higher the moral intensity of the staff/employees, the more the desire or intention to do internal whistleblowing will increase with a significance value of $0.000<0.05$.

- The regression coefficient of the Organizational Commitment variable shows the number 0.193 in a positive direction, this indicates that the higher the value of staff/employee organizational commitment will increase the desire or intention to perform internal whistleblowing with a significance value of $0.029<0.05$.

- The last regression coefficient, variable Professional Identity shows the number 0.292 in a positive direction, this indicates that the higher the value of the professional identity of staff/employees, the more they will increase the desire or intention to perform internal whistleblowing with a significance value of $0.001<0.05$. 


\subsubsection{Moderation test results}

The results of the Moderation Test in the Table 2 indicate that the significance value of each of the moderated variables has a value> 0.05. this shows that legal protection is not a variable that can moderate the Ethical Orientation of Relativism, Moral Intensity, Organizational Commitment, Professional Identity to the intention to conduct internal whistleblowing.

Table 2. Moderation test results

\begin{tabular}{lrrrrrr}
\hline \multirow{2}{*}{ Model } & \multicolumn{2}{l}{$\begin{array}{l}\text { Unstandardized } \\
\text { Coefficients }\end{array}$} & $\begin{array}{l}\text { Standardized } \\
\text { Coefficients }\end{array}$ & t & Sig. \\
\cline { 2 - 7 } & \multicolumn{1}{c}{ B } & \multicolumn{1}{c}{$\begin{array}{l}\text { Std. } \\
\text { Error }\end{array}$} & Beta \\
& 19,604 & 2,111 & & & \\
\hline Constant & 0,003 & 0,005 & 0,075 & 0,508 & 0,613 \\
The ethical orientation of relativism_M & 0,004 & 0,004 & 0,161 & 1,145 & 0,256 \\
Moral intensity_M & $-0,003$ & 0,004 & $-0,101$ & 0,683 & 0,497 \\
Organizational commitment_M & 0,004 & 0,004 & 0,145 & 0,964 & 0,339 \\
\hline
\end{tabular}

\subsection{Discussion}

The ethical orientation of relativism is one of the factors that encourages individuals to take internal whistleblowing actions at Regency Regional Work Unit in Sumenep Regency. Ethical relativism is the way individuals view right or wrong actions according to their respective views. The results of this study indicate that employees in the Regency Regional Work Unit of the Sumenep Regency Government view that whistleblowing is an ethical and commendable act because it has helped uncover a crime.

Moral intensity is one of the factors influencing the intention to conduct internal whistleblowing at Regency Regional Work Unit in Sumenep Regency. Every employee in the Sumenep Regency Regional Work Unit who has high moral intensity will tend to do something they think is good and right, including to take whistleblowing. By becoming a whistleblower, someone has tried to prevent the impact of a hidden fraud.

Organizational commitment is one of the factors affecting the intention to conduct internal whistleblowing at Regency Regional Work Unit in Sumenep Regency. Someone who is highly committed will tend to become a whistleblower. someone with high organizational commitment, they will choose to report various acts of fraud which they think will damage the image of the organization. So that becoming a whistleblower is an action to save the good name of an organization. in addition, by reporting an act of fraud to their superiors, employees will have the opportunity to demonstrate their existence to their superiors of a commitment to an institution where they are located.

Professional identity is one of the factors that influence the intention to conduct internal whistleblowing at Regency Regional Work Unit in Sumenep Regency. One of the ways to show the professional identity of employees is by looking at their loyalty when they know that there is an act of fraud or not. Professional identity is the level of individual loyalty to the profession as perceived by the individual. The act of whistleblowing can be described as a process that involves individuals and organizations, so that the higher the professionalism of an individual, they will tend to become a whistleblower. 
Legal protection is not a variable that can moderate the Ethical Orientation of Relativism, Moral Intensity, Organizational Commitment, Professional Identity to the intention to conduct internal whistleblowing. The legal protection given to whistleblowers must really be realized. As we know that whistleblowers who are also suspects in the same case cannot be exempted from criminal charges, but their courage to disclose crimes that have occurred is not an easy thing because they must be faced with various risks, therefore, legal protection must be implemented by law enforcement officials. or security forces to provide a sense of security both physically and mentally from threats, disturbances, terror and violence from any party or even being freed from legal traps in accordance with the United Nation Convention Against Corruption which is an international legal instrument regarding legal protection against whistleblowers.

\section{Conclusion}

The conclusions in this study are as follows:

- The ethical orientation of relativism is one of the factors that encourages individuals to take internal whistleblowing actions at Regency Regional Work Unit in Sumenep Regency.

- Moral intensity is one of the factors influencing the intention to conduct internal whistleblowing at Regency Regional Work Unit in Sumenep Regency.

- Organizational commitment is one of the factors affecting the intention to conduct internal whistleblowing at Regency Regional Work Unit in Sumenep Regency.

- Professional identity is one of the factors that influence the intention to conduct internal whistleblowing at Regency Regional Work Unit in Sumenep Regency.

- Legal protection is not a variable that can moderate the Ethical Orientation of Relativism, Moral Intensity, Organizational Commitment, Professional Identity to the intention to conduct internal whistleblowing.

- while the suggestions given in this study are as follows :

- With the coefficient of determination which is only $34,4 \%$, it is recommended to identify other variables that influence the intention to do internal whistleblowing such as reward, religiosity, and several other variables.

- Adding an interview element to the research process will strengthen the answers of the respondents.

The research implications of this research is expected to be a reference material for auditors of the inspectorate, especially for the Inspectorate of Sumenep Regency in designing strategies to increase the whistleblowing intention of its employees and designing or perfecting the whistleblowing system at the institution by taking into account the factors that influence the intention to take whistleblowing action. Efforts to increase the intention to take whistleblowing can be done, for example, through ethical training and comprehensive socialization on fraud, the benefits of whistleblowing, and procedures for carrying out appropriate whistleblowing. Through these efforts, it is expected to increase awareness of the impact of serious fraud and increase the positive response of auditors' attitudes towards whistleblowing. 


\section{Acknowledgement}

The authors would like to thank the Deputy for Strengthening Research and Development of the Ministry of Research and Technology/the National Research and Innovation Agency (Kemenristek-BRIN) of the Republic of Indonesia as a source of funding for the Beginner Lecturer Research program for the 2020 Funding Year according to Decree Number 8/EI/KPT/2020. The author also thanks the Universitas Wiraraja which has helped a lot.

\section{References}

[1] R. Y. Rohmaida Lestari, "Whistleblowing dan Faktor-faktor yang Mempengaruhi Niat Melaksanakannya oleh Aparatur Sipil Negara," Jurnal Akuntansi, vol. 21, no. 3, pp. 336-350, 2017.

[2] M. W. H. Sri Husniati, "Faktor-faktor yang Mempengaruhi Intensi untuk Melakukan Whistleblowing Internal: Studi pada Satuan Kerja Perangkat Daerah Kabupaten Rokan Hulu," Jurnal Online Mahasiswa Akuntansi Fakultas Ekonomi Universitas Riau (JOM FE UNRI), vol. 4, no. 1, pp. 1223-1237, 2017.

[3] P. Destriana Kurnia Kreshastuti, "Analisis Faktor-faktor yang Mempengaruhi Intensi Auditor untuk Melakukan Tindakan Whistleblowing (Studi Empiris pada Kantor Akuntan Publik di Semarang)," Diponegoro Journal of Accounting, vol. 3, no. 2, pp. 389-403, 2014.

[4] T. N. Endang Sri Wahyuni, "Analisis Whistleblowing Sistem dan Kompetensi Aparatur Terhadap Pencegahan Fraud (Studi Empiris pada Satuan Organisasi Perangkat Daerah Kabupaten Bengkalis)," Inovbiz: Jurnal Inovasi dan Bisnis, vol. 6, no. 2, pp. 189-194, 2018. 